YKSINHUOLTAJAPERHEIDEN HYVINVOINTI KANSAINVÄLISESSÄ VERTAILUSSA

Suvi Krok, YTT, tutkija, Jyväskylän yliopisto, yhteiskuntatieteiden ja filosofian laitos

Nieuwenhuis, Rense \& Maldonado, Laurie C (toim.): The triple bind of single-parent families. Resources, employment and policies to improve wellbeing. Policy Press, Bristol. 2018, 478 s.

Sukupuolentutkimuksessa yksinhuoltajaäitien perheitä on perinteisesti tutkittu sukupuolten välisen epätasa-arvon näkökulmasta. Länsimaissa kasvava yksinhuoltajaperheiden määrä merkitsee väestöllistä muutosta ja asettaa siten haasteita hyvinvointivaltiolle. Yksinhuoltajaperheiden tutkimus on laajentunut yleiseksi perheiden epätasa-arvoisuuden tutkimukseksi. Tätä tutkimussuuntaa edustaa kirja The Triple bind of single-parent families, jonka toimittajina ovat Rense Nieuwenhaus (Swedish Institute for Social Research, SOFI) ja Laurie Maldonado (City University of New York ja Columbia University School of Social Work).

Kirja on jaettu neljään osaan. Ensimmäinen osa tarkastelee yksinhuoltajaperheiden riittämättömiä resursseja. Toisessa osassa tutkitaan yksinhuoltajien työllistymisen haasteita. Kolmannessa arvioidaan, miten sosiaalipoliittisilla toimenpiteillä voidaan parantaa yksinhuoltajaperheiden asemaa. Neljännessä osassa on reflektio ja yhteenveto. Kirjoittajat ovat ruotsalaisia, yhdysvaltalaisia, belgialaisia, italialaisia, chileläisiä, espanjalaisia, islantilaisia, brittiläisiä, saksalaisia, norjalaisia ja hollantilaisia asiantuntijoita perhetutkimuksen, lasten hyvinvoinnin, hyvinvointivaltion, sukupuolen, sosiaalipolitiikan, köyhyyden ja työelämän tutkimuksen saralta.

Kirjassa on 21 artikkelia. Artikkelit tarkastelevat yhden vanhemman perheitä eri näkökulmista. Osa artikkeleista keskittyy yksinhuoltajaperheiden lapsiin kun taas osa lähestyy naisten asemaa yksinhuoltajaäiteinä. Osassa artikkeleista yksinhuoltajia tarkastellaan sukupuolineutraalisti. Artikkelit perustuvat toisistaan erillisiin kvantitatiivisiin empiirisiin tutkimuksiin. Tutkimukset pohjautuvat tilastollisiin valmiisiin aineistoihin kuten LWS database, European Social Survey tai tulotietoihin (LIS) tietyistä maista, kuten Australiasta, Kanadasta, Tanskasta, Suomesta, Ranskasta, Saksasta, Unkarista, Islannista, Luxemburgista, Alankomaista, Norjasta, Puolasta, Sloveniasta, Iso-Britanniasta ja Yhdysvalloista. Suurimmassa osassa artikkeleista vertaillaan yksinhuoltajaperheiden asemaa länsimaissa, mutta mukana on myös yhden maan kontekstiin kiinnittyviä tarkasteluja.Aineistoon Growing Up in Scotland (GUS) perustuen Morgan Treanor mittaa materiaalista puutetta ja tuloköyhyyttä suhteessa yksinhuoltajien taloudellisesti heikkoon asemaan. Ann-Zofie Duvander ja Nicklas Korsell tutkivat Ruotsissa vanhempainvapaan käyttöä erillään asuvien vanhempien kohdalla aineistona Swedish Social Insurance Agency -rekisteri. Guöný Björk Eydal käyttää tilastotietoja Islannista aineistona tutkiessaan, miten politiikka tukee yhden vanhemman perheitä Islannissa. 
Kirjan lähtökohtana on ymmärrys yksinhuoltajaperheiden heikommasta sosioekonomisesta asemasta suhteessa kahden vanhemman perheeseen. Toinen lähtökohta on nähdä yksinhuoltajaperheet heterogeenisena ryhmänä; yksinhuoltajuus ei ole staattinen, muuttumaton tila, vaan pikemminkin elämänvaihe. Kolmantena lähtökohtana on oletus, että yksinhuoltajien työllistyminen parantaa perheiden hyvinvointia, jolloin oleellista on analysoida, millaiset palvelut ja sosiaalipoliittiset päätökset helpottavat työllistymistä.

Yksinhuoltajaperheiden hyvinvointi ymmärretään monipuolisesti lasten koulumenestyksenä, työn ja perheen yhteensovittamisena, terveytenä, työllistymisenä, taloudellisena sekä emotionaalisena ja kognitiivisena hyvinvointina. Eri artikkelit keskittyvät tiettyihin hyvinvoinnin teemoihin, kuten Eva Sierminska yksinhuoltajavanhemman terveyteen, jossa tuloksena on yllättäen, että suomalaisten yksinhuoltajien terveys on heikkoa verrattuna muihin Euroopan maihin. Marloes de Lange ja Jaap Dronkers tutkivat yksinhuoltajaperheiden lasten heikkoa koulumenestystä Pisa-aineistossa. Jereon Horemans ja Ive Marx nostavat esiin työssäkäyvien yksinhuoltajaäitien köyhyyden. Suomessa kokopäivätyössä käyvän yksinhuoltajaäidin köyhyysriski on korkea verrattuna muihin Euroopan maihin. Vain Latviassa, Liettuassa, Luxemburgissa ja Norjassa on suurempi köyhyysriski.

Yli 400 sivun kirjassa tuloksena on kattava kuva yksinhuoltajaperheiden hyvinvoinnista, reunaehdoista työmarkkinoilla ja sosiaalipolitiikan antamista mahdollisuuksista eri maissa.Vaikka kirjassa tarkastellaan temaattisesti erikseen yksinhuoltajaperheiden vähäisiä resursseja, haasteita työmarkkinoilla ja sosiaalipolitiikkaa, niin kirjan ideana on kuvata työllistymisen ja sosiaalipolitiikan yhteen kietoutumista ja sen yhteisvaikutusta yksinhuoltajaperheiden hyvinvointiin. Tähän viitataan kirjan nimessä olevalla kolmoissidoksella (triple bind).

Kirjan kantava ajatus on, että ydinperhe ei ole ainoa perhemuoto, joka voi tuottaa hyvinvointia. Myös yksinhuoltajaperheet voivat olla hyvinvoivia, kun lisätään niiden resursseja ja tehdään yksinhuoltajien työllistymistä tukevaa sosiaalipolitiikkaa, esimerkiksi lisäämällä julkista päivähoitoa ja vanhempain lomia. Yksinhuoltajaperheiden heikko sosioekonominen asema ei kuitenkaan palaudu vain kolmoissidokseen vaan myös sukupuolikysymykseksi, sillä suurin osa yksinhuoltajista on naisia. Sukupuolten välinen epätasa-arvoisuus näkyy työmarkkinoilla siten, että naisten palkka on pienempi kuin miesten ja yksinhuoltajaäidin on vaikea saada hyvin palkattua työtä ja edetä urallaan.

Uuden näkökulman yksinhuoltajaperheisiin kirja tuo ymmärtämällä hyvinvoinnin laajasti, jolloin yksinhuoltajaperheiden sosioekonomista hyvinvointia ei nähdä vain tuloköyhyytenä vaan laajempana kokonaisuutena. Tällöin myös keskiluokkaiset yksinhuoltajaperheet ovat tutkimuskohteena eikä yksinhuoltajaäitejä tarkastella vain homogeenisena ja stigmatisoituneena ryhmänä. Kirjan tavoitteena on tarkastella monipuolisesti kolmoissidosta, resursseja, työllistymistä ja sosiaalipolitiikkaa, suhteessa yksinhuoltajaperheiden 
hyvinvointiin eri maissa ja tässä kirja onnistuu erinomaisesti.

\section{RuOTSALAislasten KOKEMUKSIA VUOROASUMISESTA}

Anna-Maija Castrén, apulaisprofessori, Itä-Suomen yliopisto, Yhteiskuntatieteiden laitos

Rakel Berman: Barns röster om växelvis boende:Vardagsliv, familjepraktiker och nära relationer. Göteborgs universitet, Institutionen för socialt arbete, Göteborg. 2019, 160s. Saatavilla sähköisesti: http://hdl.handle.net/2077/61729

Ruotsissa lasten vuoroasuminen eli järjestely, jossa lapsi asuu vuorotellen yhtä paljon äidin ja isän luona vanhempien eron jälkeen, on melko yleinen. Virallisten tilastojen mukaan vuonna 2014 35 prosenttia eronneiden vanhempien lapsista asui kahdessa kodissa. Suomessa tarkkaa tietoa vuoroasumisen yleisyydestä ei ole saatavilla, mutta lastenvalvojien vahvistamista sopimuksista 20 prosenttia perustuu lasten vuoroasumiseen (Forss \& Säkkinen 2019). Rakel Berman tutkii Göteborgin yliopistossa tarkastetussa sosiaalityön väitöskirjassaan vuoroasumista perheenä elämisen käytäntöinä lasten näkökulmasta. Työ keskittyy lasten kokemuksiin: miten lapset voivat vaikuttaa elämäänsä koskeviin päätöksiin ja millaista alituinen liikkeellä oleminen on käytännöllisesti, emotionaalisesti ja lasten oman toimijuuden kannalta.

Väitöskirja koostuu kolmesta artikkelista ja yhdestä kirjanluvusta. Ainoastaan yhteenvetoartikkeli eli kappa on ruotsiksi, muut englanniksi. Mukana on kolme empiirisen aineiston analyysiin perustuvaa tutkimusartikkelia ja kirjallisuuskatsaus vuosina 1984-2018 kansainvälisissä lehdissä julkaistuista vuoroasumista käsittelevistä artikkeleista. Laadullinen tutkimusaineisto koostuu 20:n iältään 9-17-vuotiaan lapsen teemahaastattelusta. Osallistujat olivat vuoroasuneet vanhempien eron jälkeen 1-14 vuotta. Kaksi vuoroasumisjärjestelyä oli toteutettu oikeuden päätöksellä, muut vanhempien sopimuksesta.

Ensimmäinen artikkeli käsittelee lasten vuoroasumista liikkumisen näkökulmasta. Huomio kohdistuu käytäntöihin (siirtymät kodista toiseen, pakkaaminen, aikataulu, ennakointi), tunteisiin, joihin liikkumisen käytännöt kietoutuvat (alituisen lähtemisen aikaansaama suru, ikävä, jälleennäkemisen odotus ja ilo) ja perhesuhteiden merkitykseen liikkumista tukevana ja/tai kuormittavana seikkana (myönteiset ja jännitteiset suhteet, joita vanhempien uusien liittojen kautta on tullut). Artikkeli kuvaa ilmaisevasti lasten tunnetyötä ja hoivaa, joka kohdistuu paitsi omaan itseen myös vanhemman kannatteluun. Berman kertoo 11- ja 13-vuotiaista siskoksista, jotka sopivat keskenään vuoroasumisaikataulun muutoksesta siten, että toinen vanhemmista ei joutuisi olemaan liian pitkiä aikoja yksin. Vuoroasumiseen liittyy myönteisiä ja kielteisiä näkökohtia; se voi joissakin olosuhteissa toimia emotionaalisen turvallisuuden lähteenä.

Journal of Family Research -lehden erikoisnumerossa vuonna 2015 ilmestynyt toinen artikkeli nojautuu vahvasti brittisosiologi David Morganin 
ajatukseen perheestä ja perhesuhteista jonakin, jota aktiivisesti tehdään. Huomio on siinä, miten lapset muokkaavat suhdettaan vanhempiin eron jälkeen ja millaisena he ajattelevat ja kokevat nämä suhteet uudessa tilanteessa. Joidenkin kohdalla suhde oli muuttunut läheisemmäksi ja lapset kokivat saavansa enemmän huomiota vanhemmaltaan kuin aiemmin. Kaikilla tällaista kokemusta ei ollut, vaan näkemys omasta elämästä ja suhteista verrattuna muiden perheisiin oli karu; mitään lähentymistä ei ollut tapahtunut, vapausasteita elämässä oli vähän ja näin elettiin nyt, koska vanhemmat olivat niin päättäneet.

Kolmas artikkeli käsittelee lasten mahdollisuutta vaikuttaa elämäänsä. Vaikka tässäkin artikkelissa ajatus perhekäytännöistä on tärkeä, analyysi nojautuu vahvasti lapsuuden sosiologiseen tutkimukseen ja keskusteluun lapsista toimijoina. Lähtökohtana on Bren Nealen ja Jennifer Flowerdewn (2007) muotoilema käsitys lapsen toimijuudesta aina relationaaliseen kontekstiin kiinnittyneenä. Se ei siis ole autonominen prosessi, vaan riippuvainen muilta saadusta tuesta. Berman havainnollistaa esimerkein olosuhteita, joissa lapsen vaikutusvalta jokapäiväisen elämänsä järjestämiseen on verrattain suuri. 16-vuotias haastateltu kertoo saaneensa itse valita asumisjärjestelynsä neljä vuotta sitten tapahtuneen eron jälkeen ja voivansa liikkua vapaasti kahden kodin väliä. Haastateltavalla on paljon vaikutusvaltaa, mutta hän kokee päätöksenteon vaativan monien asioiden huomioon ottamista ja yksityiskohtien tarkistamista. Tilannetta helpottaa, että vanhemmilla ei ole uusia puolisoita, joiden aikataulujen ja toiveiden huomioiminen mutkistaisi kokonaisuutta. Joillakin haastatelluilla lapsilla vaikutusvaltaa oli huomattavasti vähemmän ja kahdella lapsella ei kokemuksensa mukaan ollut minkäänlaista roolia oman elämänsä järjestelyissä. Artikkelissa siteerattu 17-vuotias oli elänyt vanhempien tulehtuneiden välien keskellä 10 vuotta sitten tapahtuneesta erosta saakka. Vanhempiensa tunteiden loukkaamisen ja keskinäisen konfliktin eskaloitumisen pelossa hän ei ilmaise toiveitaan asumisen suhteen, vaan suuntautuu tulevaisuuteen; muutaman vuoden päästä päättyy koulu ja hän pääsee muuttamaan omilleen.

Neljäs artikkeli on yhdessä Kristian Danebeckin kanssa laadittu kirjallisuuskatsaus lasten vuoroasumista koskevasta tutkimuksesta. Aineistona on 111 englanninkielistä eri tutkimusalojen piirissä toteutettua tutkimusartikkelia. Aineiston muodostaminen kuvataan katsauksessa huolellisesti ja artikkeli valottaa hyvin vuoroasumista koskevan tutkimuksen suosion lisääntymistä, maantieteellistä sijoittumista ja vuoroasumisen määrittelyssä ilmeneviä eroja maiden välillä. Vuoroasumisen määrittelyssä käytetty ajan jakautuminen vaihtelee 25/75-jaosta 50/50-jakoon. Suurin osa tutkimuksista on tilastollisia analyyseja 100-15 000 vastaajan aineistoista, laadullisia tutkimuksia on vain 17. Vaikka aiheissa oli vaihtelua, lapsen hyvinvointiin ja sopeutumiseen sekä perheiden erityispiirteisiin keskittyviä analyyseja oli eniten. Tulosten mukaan monilla hyvinvointiin liittyvillä kriteereillä mitattuna vuoroasuvat lapset voivat yhtä hyvin ja joskus jopa paremmin kuin pääasiassa vain yhden vanhemman kanssa elävät lapset. Näin oli silloin, kun järjestely perustui vanhempien 
sopuisalle yhteistyölle (ei väkivaltaa, ei konfliktia tai konflikti vain vähäinen) ja lapsi oli yli neljävuotias. Kirjoittajat pohtivat vuoroasuvien vanhempien valikoitumisen vaikutusta, sillä vuoroasuvien lasten vanhemmilla on muissa järjestelyissä elävien vanhempiin verrattuna suuremmalla todennäköisyydellä korkeampi koulutus, korkeammat tulot, vähemmän konflikteja, sitoutuneempaa vanhemmuutta ennen eroa ja kodit lähempänä toisiaan.

Bermanin tutkimuksen mukaan lasten kokemukseen vuoroasumisesta vaikuttavat merkittävimmin lasten sosiaaliset suhteet. Muita olennaisia seikkoja ovat vanhempien kyky yhteistyöhön, lapsen vaikutusvalta itseään koskevissa asioissa, järjestelyn käytännölliset ja materiaaliset reunaehdot ja lapsen yksilölliset tarpeet. Jokaisen lapsen yksilölliset piirteet ja tarpeet nousevat keskiöön, ja se, mikä yhdelle lapselle sopii, ei välttämättä sovi toiselle.

Väitöskirja on korkeatasoinen ja huolellisesti toteutettu kokonaisuus, joka myös taustoittaa suomalaislukijalle kiinnostavasti vuoroasumisjärjestelyn yleistymisen ruotsalaisessa yhteiskunnassa. Käy ilmeiseksi, että naapurimme reitti eroaa meidän polustamme. Ruotsissa sukupuolten tasa-arvon edistäminen ja vanhemmuuden vastuiden jakaminen tuli vahvasti osaksi julkilausuttua politiikkaa ja yhteiskunnallista ohjausta jo 1970-luvulla. Vuoroasumiseen on suhtauduttu tästä kehyksestä lähtien lasten oikeutena saada vanhemmiltaan eron jälkeen samaa hoivaa kuin ennen eroa. Taustalla on siis johdonmukaista politiikkaa vanhemmuuden tasapuolisemman jakautumisen edistämisek- si lapsen elämän alusta saakka, ei vain eron tapahduttua. Tässä kohden ero suomalaiseen yhteiskuntaan on ilmeinen. Meillä vanhempainvapaiden jakaminen on lisääntynyt hitaasti, jopa vaivalloisesti, ja vuoroasumisen oikeudellinen tunnustaminen edennyt takapotkulla (ks. Koulu tässä numerossa). Julkista keskustelua vuoroasumisesta sanomalehtien yleisönosastokirjoituksissa on hallinnut tasa-arvonäkökulma. Bermanin väitöskirja ei tartu meidän keskusteluumme, tietenkään, mutta erinomaisessa taustoituksessaan ja huolella toteutetun analyysin ansiosta se valottaa suomalaisyleisöäkin hyödyttävällä tavalla vuoroasumista lasten jokapäiväisen elämän käytäntönä, jossa on yhtä hyvin kurjia kuin ilahduttaviakin piirteitä.Työ nostaa esiin seikkoja, jotka kannattaa pitää mielessä käytännön työssä. Myös tutkimuksellisesti väitöskirja on rikas, inspiroiva ja erittäin informatiivinen kokonaisuus, josta monet voivat hyötyä.

\section{KirjallisuUs}

Forss Anne \& Säkkinen Salla (2018) Lapsen elatus ja huolto sekä isyyden selvittäminen 2018. Tilastoraportti 11/2019. Helsinki: Terveyden ja hyvinvoinnin laitos.

Neale Bren \& Flowerdew Jennifer (2007) New structures, new agency: The dynamics of child-parent relationships after divorce. The International Journal of Children's Rights 15 (1), 25-42. https:// doi.org/10.1163/092755607x185546 
LAPSET, MONIPAIKKAISUUS JA EROT

Heidi Ruohio, VTT, yliopistonopettaja, Yhteiskuntatieteiden ja filosofian laitos, $J y$ väskylän yliopisto

Hannele Forsberg \& Aino RitalaKoskinen (toim.): Monen kodin lapset. Lasten monipaikkainen asuminen ja sosiaalityö. Gaudeamus, Helsinki. 2018, 222s.

Tampereen yliopiston sosiaalityön professori Hannele Forsberg ja yliopistonlehtori Aino Ritala-Koskinen ovat toimittaneet vuonna 2018 julkaistun kokoomateoksen, jossa pureudutaan lasten monipaikkaiseen asumiseen. Kirjassa lähestytään aihetta kolmen lapsia liikuttavan ilmiön kautta: eron jälkeinen vuoroasuminen, lastensuojelu ja globaalit muuttoliikkeet. Näitä kaikkia kirjassa käsiteltyjä muuttoliikkeitä ja niistä syntynyttä monipaikkaisuutta voidaan pitää enemmän tai vähemmän pakotettuina. Muuttopäätöksissä lapset ovatkin usein aikuisten, kuten vanhempiensa ja viranomaisten, armoilla. Vaikka lasten toimijuus muuttoliikkeen synnyssä on siis pientä, kirjan artikkeleissa käsitellään monipaikkaisuutta nimenomaan lapsen näkökulmasta. Kirja onkin tärkeä puheenvuoro nimenomaan lapsen kokemuksen esiin tuomiseksi.

Kirjan teoreettiset kytkennät juontuvat humanistisesta maantieteestä ja läheissuhteisiin liittyvästä asumisliikkuvuuden tutkimuksesta (engl. intimate mobilities), yhteiskuntatieteellisestä lapsuudentutkimuksesta sekä lasten hyvinvoinnista, asumisesta ja kodista kiinnostuneesta sosiaalityön tutkimuksesta. Tutkimuksessa ei ole tätä kirjaa aiemmin juurikaan kiinnitetty huomiota lasten asumispolkuihin tai lasten näkökulmaan heitä koskevissa asumisratkaisuissa. Vaikka kirjan toimittajat ovat sosiaalityön tutkijoita, monipaikkainen asuminen koskettaa jollakin tavoin hyvin suurta osaa lapsia. Se koskettaa esimerkiksi eroperheitä, joissa lapsen arki jakautuu rinnakkaisesti kahteen kotiin. Vuoroasuminen esitetään usein mediassa melko ongelmattomana ja toivottavana asumisratkaisuna eron jälkeiseen tilanteeseen. Ilmiön yleisyyden vuoksi onkin häkellyttävää, että aiheesta ei ole juurikaan tutkittua tietoa lapsen näkökulmasta. Tällä hetkellä sen mahdollisuus on määrä kirjata myös lakiin, joten aihe on hyvin ajankohtainen.

Kirja koostuu johdannosta, kuudesta empiiriseen aineistoon perustuvasta luvusta sekä yhteen vetävästä lopetusluvusta. Lukijana olin hiukan pettynyt empiriaan perustuvien lukujen vähäisyydestä. Tätä kirjaa voidaan kuitenkin pitää jonkinlaisena pääavauksena Suomessa, ja sellaisena se toimii hyvin. Kirjan empiirisiin tutkimuksiin perustuvat luvut pureutuvat hyvin eri tasoisiin muuttoliikkeisiin liittyviin ilmiöihin, mitä voidaan pitää sekä vahvuutena että haasteena. Olisin mielelläni lukenut aiheesta huomattavasti enemmän, vielä useammista näkökulmista ja erilaisin aineistoin. Nyt kirjan luvut nojaavat valtaosin haastatteluaineistoihin, mikä on toki kohderyhmän vuoksi ymmärrettävää. Käyn seuraavaksi lyhyesti läpi lukujen aiheet ja tulokset. 
Hannariikka Linnavuori käsittelee artikkelissaan pitkittäisaineistonsa perusteella lasten kokemuksia vanhempiensa eron jälkeisestä vuoroasumisesta. Linnavuoren aineisto on ainutlaatuinen pitkittäisaineisto, jossa toinen aineiston keruun kohta on ollut nuorina aikuisina. Näin ollen aineisto antaa kiinnostavaa tietoa lasten pitkältä vuoroasumisen uralta. Suurin osa osallistujista piti vuoroasumista hyvänä, mutta jatkuva tavaroiden siirtäminen ja sopeutuminen aina uudestaan toisen vanhemman tavoille koettiin ajoittain hankalana. Leena Autonen-Vaaraniemi taas keskittyy vuoroasumisen kontekstissa tapahtuvaan vanhempien väliseen riitelyyn. Lapset kokivat vanhempien riitelevän eniten lasten asioiden hoitamisesta, kuten sovituista aikatauluista poikkeamisista, tavaroiden unohduksista ja sääntöjen erilaisuuksista. Mikäli vanhemmat eivät kyenneet kommunikoimaan lapsen asioista keskenään, lapsi joutui usein viestinviejäksi. Luku tuo esille lapsen pyrkimyksen olla lojaali molempia vanhempiaan kohtaan. Strategiana tässä toimi usein riitojen ulkopuolelle asettuminen.

Kirjan toisessa osassa keskitytään lastensuojelun kontekstiin. Aino RitalaKoskinen tarkastelee artikkelissaan lastensuojelun avohuollon lasten monipaikkaisuutta. Monipaikkaisuus on tässä kontekstissa yleistä paitsi lapsen vanhempien erojen ja muuttojen, myös esimerkiksi tukiperhetoiminnan ja erilaisten kuntoutusjaksojen vuoksi. Artikkeli tuo kiinnostavalla tavalla esille sen, kuinka lastensuojelun palvelut lisäävät usein jo entuudestaan monissa paikoissa rinnakkaisesti elävän lapsen monipaikkaisuutta. Tukiperhetoimin- nan tarkoitus on toki auttaa sekä lasta että perhettä, mutta samanaikaisesti se lisää lapsen elämään uusia paikkoja ja ihmisiä. Monipaikkaisuus ei näyttäydy kuitenkaan vain kielteisenä, vaan myös kannattelevana. Riitta Laakson artikkelin kontekstina taas on lastensuojelun viimesijainen toimenpide eli huostaanotto. Laakso keskittyy tarkastelemaan esineiden merkitystä huostaan otettujen lasten muutto- ja paikkakokemuksissa. Hänen tutkimuksensa mukaan huostaan otetut lapset tekevät esineillä tilasta persoonallisen ja oman. Lisäksi tietyt esineet, kuten tietokone ja kännykkä, pitävät yllä jatkuvuutta mahdollistamalla yhteydenpidon kavereihin ja perheeseen. Monet sijaishuoltopaikat kuitenkin rajoittavat näiden käyttöä, mikä osaltaan voi lisätä lasten epätasaarvon ja irrallisuuden kokemusta suhteessa ikätovereihin. Esineet toimivat näille lapsille myös arvostuksen ja välittämisen osoituksina - ne ovat jotakin ikiomaa,juuri häntä varten hankittua ja siksi tärkeitä.

Kolmas osio kirjasta keskittyy globaaliin muuttoliikkeeseen. Anu Warinowski käsittelee ekspatriaattilasten muuttoliikekokemuksia ja Outi Kauko alaikäisten turvapaikanhakijoiden monipaikkaisuutta. Warinowskin artikkeli paljastaa ekspatriaattilasten dynaamisen kokemuksen kuulumisesta iässä, jossa kavereihin ja paikkaan kiinnittyminen on hyvin keskeistä. Artikkelissa kiinnittää huomion eräs sitaatti, jossa lapselle on annettu päätösvalta siitä, missä vaiheessa perhe palaa takaisin Suomeen. Ei liene kovin harvinaista kysyä lasten mielipidettä muutosta ja huomioida sitä perheen päätöksessä, mutta kyseinen esimerkki tuo hyvin 
esille "ylitoimijuuden" ongelman silloin, kun päätösvastuu sälytetään kokonaan lapselle. Ylitoimijoiksi joutuvat myös turvanpaikanhakijalapset, jotka edustavat pakotettua siirtolaisuutta par excellence. Yksin matkustaminen vieraaseen maahan vailla perhettä asettaa nämä lapset hyvin haavoittuvaan asemaan. Suomeen tullessaan heillä oli edelleen useita muutoksia asuinpaikoissaan, joihin heillä ei ollut sananvaltaa. Asuinpaikkojen yhtäkkisten muutosten vuoksi kodin tekeminen on käytännössä mahdotonta. Heidän kotinsa olikin usein "kotimaassa" tai "omassa maassa", sillä emotionaaliset kiintymykset olivat siellä, missä olivat läheiset suhteet -tai ainakin muistikuvat läheisistä ihmisistä. Warinowskin ja Kaukon artikkelien lapsia liikuttavat globaalit muuttoprosessit tekevät tahtomattaankin näkyväksi epätasa-arvon näiden lapsien välillä. Kun ekspatriaattilapsia koskevassa luvussa penätään tarvetta tunnistaa lasten mahdollinen palveluntarve, seuraavan luvun lapsilla ei ole oikeutta edes perheeseen. Peräkkäisinä lukuina ne nostattavat lukijalle tuskanhien siitä hä- peästä, miten Suomi kohtelee turvapaikanhakijalapsia.

Forsbergin ja Ritala-Koskisen toimittama kirja on tärkeä herättelevä puheenvuoro paikkatietoisempaan sosiaalityöhön ja palveluihin. Tulevaisuudessa toivon voivani lukea lisää myös mentaalisten tilojen ja paikkojen merkityksestä fyysisten ohella. Kirjassa on tärkeä viesti vanhemmille ja sosiaalityön ammattilaisille siitä, että lapsilla on tarve ja halu kiinnittyä paikkoihin. Kirjan lopettavassa luvussa keskustellaan monipaikkaisuudesta vielä kuulumisen käsitteen kautta. Mielestäni kuulumisen käsitteellä olisikin paljon annettavaa sosiaalityön tutkimukselle, joka Suomessa vielä varsin vähän teoretisoi tai hyödyntää käsitettä analyyttisesti. Tämä kirja on jo varmasti löytänyt monen tutkijan ja opiskelijan työpöydälle, ja toivottavasti innostaa lukijoitaan kiinnittämään huomiota tilojen ja paikkojen merkitykseen yksilön kiinnittymiselle, kuulumisen kokemukselle ja sitä kautta hyvinvoinnille. 